\title{
Comparative study of growth and laying performance of indigenous layer guinea fowls (Numida meleagris) from Upper East, Upper West and Northern Regions of Ghana
}

\author{
Agbolosu, A. A., Teye, G. A., Jebuni, S. N., Ansah, T. and Naandam, J. \\ Animal Science Department, University for Development Studies, P. O. Box TL 1882, \\ Tamale; Tel: 0246388872 , \\ Corresponding Author's email address: anthonyagbolosu@yahoo.com.
}

\begin{abstract}
An eleven-week experiment to compare the performance of 45 weeks old local layer guinea fowls from Upper East (UER), Upper West (UWR) and Northern (NR) regions of Ghana was conducted at the Animal Science Department farm of the University for Development Studies, Tamale. 243 birds, 86 from UER, 79 from UWR and 78 from NR were used. Birds from each region were divided into four groups and put into four cages each. The diet was made up of $25 \%$ layer concentrate, $55 \%$ maize and $20 \%$ wheat bran. Water was provided ad libitum. Parameters measured were feed intake (FI), body weight, and weight gain, feed conversion efficiency (FCE), mortality, rate of egg laying and fertility. There were no significant differences $(P>0.05)$ in $\mathrm{FI}$ and FCE of birds from the three regions. UWR birds were more efficient in feed conversion than birds from UER and NR. Mortality was generally low. Birds from UWR laid more eggs (631) while UER birds recorded the lowest (352 eggs). Egg fertility was high (74\%) with NR birds but low in UER (53.6\%) and UWR birds (43\%). UWR birds exhibited high potential for egg production and FCE than those from the UER and NR. NR birds performed fairly well in egg production and body weight gain. UER birds laid fewer eggs though they had large body size indicating they possess meat production tendencies.
\end{abstract}

Keywords: Comparative study, Layer guinea fowls, growth performance, mortality

\section{INTRODUCTION}

Background of Study: Guinea fowls play a significant role in the lives of people in Northern Ghana, ranging from socio-cultural to economic and religious purposes. They are the commonest among the numerous poultry species in Northern Ghana (Upper East, Upper West and Northern Region) where they have been estimated to be about 4 million (Koney, 1993) and are reared entirely by the extensive system. Their production is abound with potential for both meat and eggs (Biswas, 1999).

With the realization for increased animal source of protein in the diets of the average Ghanaian, it is becoming increasing important to adopt efficient methods to improve animals' production. This will involve changes in management, husbandry practices and provision of adequate and appropriate health schemes (Koney, 1992). It is in this direction that local laying guinea fowls were reared to determine these production potential levels of productively and unearth ways to improve them. It has been found that, they are highly productive indigenous birds. However, there is still lack of information about the production characteristics of the locally available breeds managed under extensive system and insufficient knowledge of their breeding strategies.

It has well been identified that very little is done in terms of scientific research into the production, management and improvement of the indigenous guinea fowls as compared to domestic chicken (Maganga and Haule, 1994; Maphosa et al., 2002 and Machadeyi et al., 2004). For this reason, the Animal Science Department of the Faculty of Agriculture, University for Development Studies is carrying out research into the guinea fowl production in the areas of management, improvement, appropriate husbandry practices and conservation of the local guinea fowls to assess their performance.

This study is a continuation of earlier work carried out on the guinea fowls that were brought from the three Northern Regions (Upper East, Upper West and Northern) of Ghana and therefore seeks to achieve following objectives. 
1. To ascertain the level of performance of the birds (local guinea fowls) that was brought from the three Northern regions with regard to their feed intake, body weight gain (weekly and daily weight), feed conversion efficiency and mortality.

2. To compare the laying performance of the local fowls from the three regions.

3. To assess how management system (housing, feeding and medication) will improve their productivity (egg numbers and fertility).

\section{MATERIALS AND METHODS}

Study area: The experiment was carried out at the Animal Science Department Farm of the University for Development Studies, Nyankpala CampusTamale where the birds procured from the various Regions (Upper East, Upper West and Northern) were confined and reared.

The location is about $16 \mathrm{~km}$ west of Tamale and lies on latitude $9^{0} 25^{\prime} 41^{\prime \prime} \mathrm{N}$ and longitude $0^{0} 52^{\prime} 42^{\prime \prime}$ in the Guinea Savanna Zone. It has an average rainfall and temperature of $1024.4 \mathrm{~mm}$ and $28.3^{\circ} \mathrm{C}$ respectively (SARI, 2004). The study area is characterized by very long period of dry season ranging from October to March. Bushfires are rampant and pose threat to both fauna and flora. Trees that can withstand fire are only found in this area. The vegetation consists of short grasses interspersed with tree.

Experimental birds: The experimental birds were 45 week old local guinea fowls from Upper East, Upper West and Northern Regions of Ghana. A total of 243 birds consisting 86 (25 cocks, 60 guinea hens), 79 (19 cocks, 60 guinea hens) and 78 (18 cocks, 60 guinea hens) from Upper East, Upper West and Northern Regions respectively were used.

\section{Management of experimental birds}

Housing: The birds were intensively housed in a deep litter system. There were two rooms (pen I and Pen II) each having six cages totaling twelve (12) cages in all. Four cages were randomly allocated to birds from each region in each pen. All the replications were given equal treatment throughout the experiment.

Formulation of experimental diet: Layer concentrate, maize and wheat bran were the ingredient in the experimental diet. The ingredients were thoroughly mixed and the quantity to be given to birds at any time was moistened with water. Below is a table which shows the nutrient composition of the concentrate used.
Table 2: Layer Concentrate Inclusion Rate 25\%

\begin{tabular}{|l|c|}
\hline Nutrients & Percentage (\%) \\
\hline Protein (min) & 35.00 \\
Fat (min) & 5.00 \\
Fibre (max) & 4.00 \\
Calcium & 12.00 \\
Average phosphorus & 1.15 \\
Lysine & 1.90 \\
Methionine & 1.95 \\
Salt & 1.60 \\
ME (kcal/kg) & 1940 \\
\hline
\end{tabular}

The concentrate composed of fishmeal, soya bean meal, copra cake, wheat middling calcium carbonate, vitamin $A$, and D3, B12, E, K, riboflavin, Sodium chloride, niacin, folic acid, ethoxyquin and calcium propionate.

The proportions of ingredient used for the feed formulation are shown below in Table 3

Table 3: Proportion of ingredients for formulation

\begin{tabular}{|l|c|c|}
\hline Ingredient & Quantity (kg) & Percentage (\%) \\
\hline Concentrate & 25 & 25 \\
Maize & 55 & 55 \\
Wheat bran & 20 & 20 \\
Total & $\mathbf{1 0 0}$ & $\mathbf{1 0 0}$ \\
\hline
\end{tabular}

Feeding, watering and Medication: Feed was measured and given to birds every morning. The leftover was weighed the following morning to determine the amount consumed before giving fresh feed. Water was provided ad libitum. Birds were given multivitamin as prophylaxis and dewormers periodically.

Data collection: The data was collected over a period of ten (10) weeks. The body weights of the birds were recorded weekly while feed intake was measured daily. Daily eggs collected were recorded and mortality was noted as and when it occurred.

Feed intake: Feed were measured or weighed and given to birds in the morning and the left over (if any) were weighed the following morning from each cage or replication. Moist feed were further sun dried before weighing. The difference between the quantity of feed given and the left over represented the feed intake of the birds.

Body weight: The birds were weighed weekly early in the morning before feeding. Ten (10) birds were randomly picked from each cage or replication and 
weighed together. A large perforated empty cardboard box and a weighing scale were the main instruments used. The box during weighing is first put on the weighing scale and adjusted to zero. All the ten birds then put into box at a go and weight taken. The mean weekly weights of the birds were recorded and the weight gain derived.

Feed conversion efficiency: Feed conversion is the ratio of feed consumption per unit increase in weight or quantity of eggs produced. Feed conversion efficiency was obtained from the measure of the body weight gain and the feed intake. Thus FCE=weight gain/feed intake.

\section{Productivity (Egg Number and Fertility)}

Egg Numbers: Eggs from the birds were collected three times daily thus in the morning, afternoon and evening. The date and region on which the eggs were collected were written on the eggs with a pencil and stored separately according to the regions. Number of eggs collected from each cage per day was recorded accordingly.

Fertility: This was determined by candling eggs collected from birds of the three regions during incubation. Candling was done by using a wooding Candler at the Animal Research Institute (ARI). The Candler was made of wood with a sixty (60) watts bulb enclosed in it. The eggs were put one after the other on top of the Candler in a dark room at the $8^{\text {th }}$ $12^{\text {th }}$ day of incubation. The opaque eggs which did not allow light to pass through them were considered fertile while the transparent ones were considered infertile.

Data analysis: The data was analyzed using GENSTAT version (Seventh Edition) and the various means separated using Least Significant Difference (LSD) at $5 \%$ significance level.

\section{RESULT AND DISCUSSION}

Comparative Study: The results of the comparative study on the performance of the laying guinea fowls from the various regions are summarized below:

Feed intake: Below is a graph showing the feed intake of birds from the three regions from the first to the tenth week. The overall mean feed intake per bird per day was about the same for all the birds from the three regions. However birds from the Upper West Region consumed less feed per day whereas birds from the Upper East ate much more feed per day than those from Northern and Upper West Region. Furthermore, there was significant difference
Table 4: Performance of guinea fowls from Upper East, Upper West and Northern Region of Ghana

\begin{tabular}{|l|c|c|c|c|}
\hline \multicolumn{1}{|c|}{ Parameters } & $\begin{array}{c}\text { Upper } \\
\text { East }\end{array}$ & $\begin{array}{c}\text { Upper } \\
\text { West }\end{array}$ & Northern & $\mathbf{\pm}$ s.e.d \\
\hline $\begin{array}{l}\text { Mean feed } \\
\text { intake/bird/day } \\
\text { (g) }\end{array}$ & 49.6 & 47.6 & 48.8 & $0.1966^{* * *}$ \\
$\begin{array}{l}\text { Mean body } \\
\text { weight/bird/week } \\
\text { (g) }\end{array}$ & $1290.8_{\mathrm{a}}$ & $1274.1_{\mathrm{b}}$ & $1294.5_{\mathrm{a}}$ & $1.354^{* * *}$ \\
$\begin{array}{l}\text { Mean weight } \\
\text { gain/bird/day (g) }\end{array}$ & $5.71_{\mathrm{a}}$ & $10.7_{\mathrm{b}}$ & $6.1_{\mathrm{a}}$ & $0.0819^{* * *}$ \\
$\begin{array}{l}\text { Feed conversion } \\
\text { Total eggs }\end{array}$ & $0.1_{\mathrm{b}}$ & $0.2_{\mathrm{a}}$ & $0.1_{\mathrm{b}}$ & $0.0387^{* * *}$ \\
\hline
\end{tabular}

Means with difference subscript on the same row are significantly different $(P<0.05)$ s.e.d $=$ Standard Error of difference. NS-Not Significant $(P>0.05)$

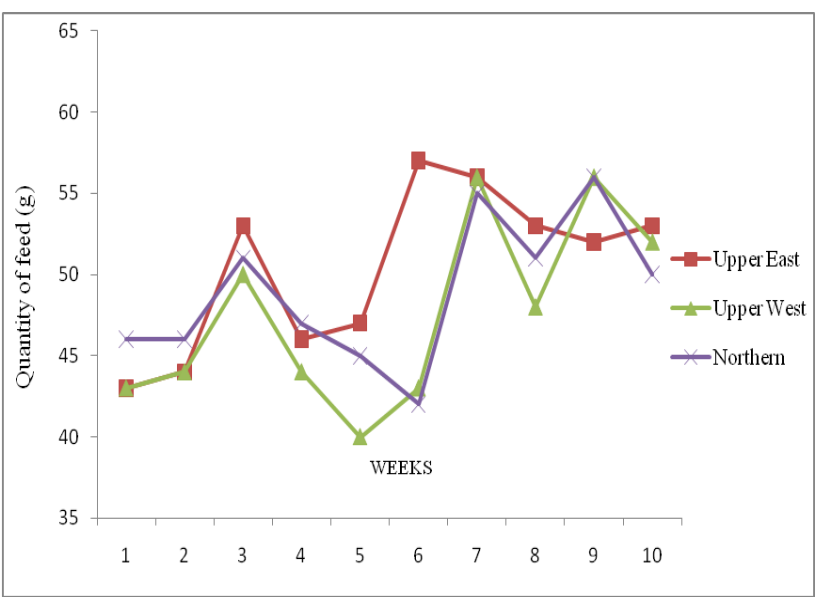

Fig 1: Feed intake per bird per day (g)

$(p<0.05)$ in feed intake over weeks. Generally, the weekly feed intake of the birds fluctuates over the period. The feed intake increased slightly at the latter part of the experiment $\left(7^{\text {th }}-10^{\text {th }}\right.$ week) when cold or harmattan set in.

This therefore confirms as stated by Oluyemi and Roberts (1979) that cold weather or low temperature increases feed intake. Increase in age and weights of birds during the experiment could have also accounted for the increase in feed intake at the latter part. Around the middle of the experiment $\left(4^{\text {th }}-6^{\text {th }}\right.$ week), there was a decrease in feed intake among all the birds with the resultant decrease in body weight but egg production increased as depicted in figure 
1,2 and 3 . This could be due to the fact that there was no excess feed conversion into weight but used in egg production.

Body weight: There was significant difference $(\mathrm{P}<0.05)$ in body weight between birds from the three regions. There was significant difference $(P<0.05)$ in body weight between birds from Upper East, and Upper West Region and also between Northern Region and Upper East Region birds. However, there was no significant difference ( $P$ 0.05) between birds from Northern Region and Upper East Region in terms of body weight. This might be because, birds from Upper East Region and Northern Regions were similarly large in size compared to those from Upper West Region. The variation in body weight among the birds from the three regions could be attributed to their genetic make-up or traits that infringe on them.

Weekly differences in body weight were also observed with birds recording higher body weights at the latter part of the experiment. This is in accordance with Smith (1990) that birds do put on weight throughout the laying cycle. The increase in body weight could have been attributed to the increase in feed intake. This is because Daghir (1995) stated that birds increase in weight when feed intake increases and weight declines when feed intake drops.

Below is a graph showing the body weight of birds from the various regions.

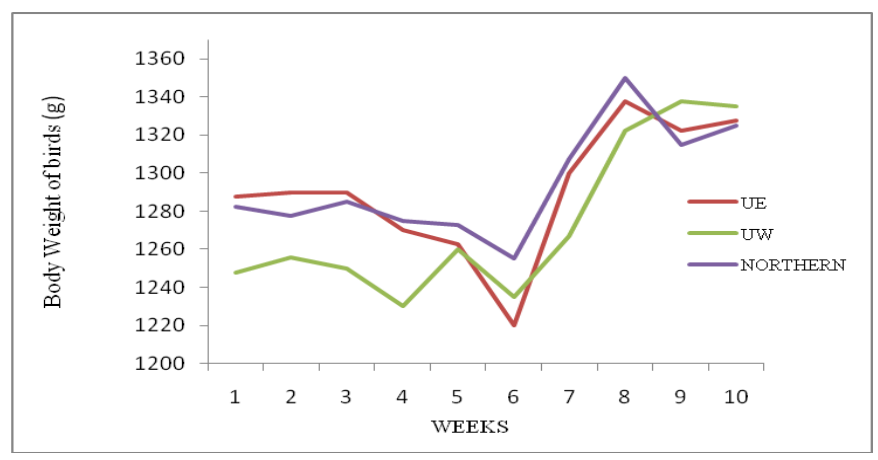

Fig 2: Weekly Body weight per bird per week

Weight Gain: From Table 4, there was no significant difference $(P>0.05)$ in the daily weight gain between birds from Upper East and Northern Regions. There was a significant difference $(P<0.05)$ between birds from Upper West and those from Upper East Regions in the body weight gain as well as between Upper West and Northern Regions birds. Though birds from the Upper West Region consumed less feed as compared to their counterparts from the other two regions, they tend to record higher weight gain. This is reflected in the higher FCE ratio of 0.2. Birds from Upper East Region recorded the lowest weight gain of $(5.7 \mathrm{~g})$ though they consumed more feed than birds from the other regions.

Feed Conversion Efficiency (FCE): There was no significant difference $(P>0.05)$ in FCE between Upper East and Northern Region birds. However, there were differences observed $(P<0.05)$ between birds from Upper West and those from Upper East and Northern Region. Birds from Upper West Region recorded the highest FCE of 0.2 among the birds from the three regions. Generally, all the birds from the three regions recorded very low feed conversion ratios. This suggests that guinea fowls have less efficient feed conversion ability as compared to domestic chicken Smith (1990).

\section{Productivity}

Egg collected (Numbers) and Egg Fertility : Eggs collected from Upper West birds (631) were significantly higher $(P<0.05)$ than those collected from Upper East (352) and Northern Regions (482).

However, there was no significant difference $(P>0.05 \%)$ in the eggs laid between Upper East and Northern Region birds. Birds from Upper West Region consumed less feed and were also more efficient in feed conversion despite their small size. The Upper West Region birds therefore portray the potential for egg production compared to those from Upper East and Northern Regions. Birds from Northern Region did fairly well in egg production. Birds from Upper East Region produced the least number of eggs. The low egg production with birds from Upper East Region could be attributed to the fact that the experimental period did not coincide with the laying seasons. According to Anamoh (1994) there is major and minor laying seasons for guinea fowls in Ghana. The major laying season coincides with the raining moths of May-July and the minor season covers December-March. This finding is contrary to earlier studies by Adjetey (2006) on the guinea fowls where birds from Upper East Region tend to produce more eggs. The reason for the low egg production by birds from Upper West Region during the first study could have been due to the fact that the birds were still acclimatizing to the environment.

Figure 3 below shows the weekly egg collection from the birds during the experiment. The results of the egg fertility are presented below in Table 5. Fertility of 
eggs of birds from Northern Region was good (74\%), but those from Upper East (53.6\%) and Upper West birds $(43 \%)$ were not satisfactory. The high percentage of infertile eggs from Upper West birds $(57 \%)$ could be due to the fact that they were laying more eggs hence at faster or regular pace. Therefore, the low fertility could be attributed to infrequent mating and low volume, concentration and motility of semen. The poor fertility could also

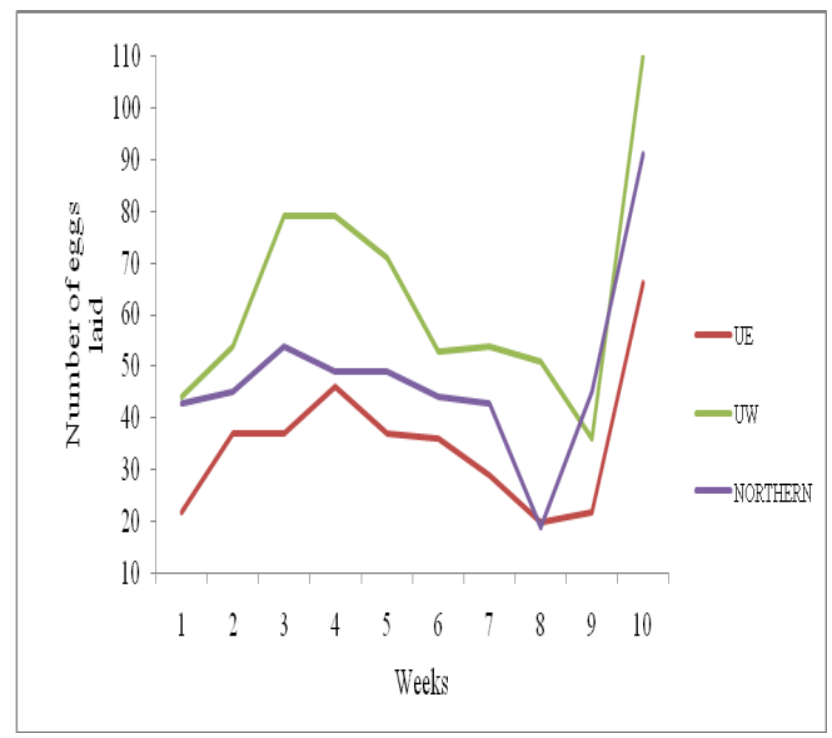

Fig 3: Weekly egg collection of birds from UER, UWR AND NR

Table 5: Fertility and fertility ratios of eggs laid by birds from the three regions

\begin{tabular}{|c|c|c|c|}
\hline Parameter & $\begin{array}{l}\text { Upper } \\
\text { East }\end{array}$ & $\begin{array}{l}\text { Upper } \\
\text { West }\end{array}$ & Northern \\
\hline $\begin{array}{l}\text { Total number of } \\
\text { eggs }\end{array}$ & 352 & 631 & 482 \\
\hline $\begin{array}{l}\text { Number of fertile } \\
\text { eggs (\%) }\end{array}$ & 189 & 271 & 357 \\
\hline $\begin{array}{l}\text { Percentage of } \\
\text { fertile eggs (\%) }\end{array}$ & 53.6 & 43 & 74 \\
\hline $\begin{array}{l}\text { Number of infertile } \\
\text { eggs }\end{array}$ & 163 & 360 & 125 \\
\hline $\begin{array}{l}\text { Percentage } \\
\text { infertility (\%) }\end{array}$ & 46.4 & 57 & 26 \\
\hline
\end{tabular}

result from high temperatures since according to Kekeocha (1984) that high temperature (above $30^{\circ} \mathrm{C}$ ) can reduce egg fertility since the temperature in the afternoons at the study area usually goes above $30^{\circ} \mathrm{C}$.

\section{Mortality}

Table 6 below shows the mortality and survival rates of guinea fowls from the three regions during the experimental period

Table 6: Mortality and survival rate of the guinea fowls from Upper East, Upper West and Northern Regions.

\begin{tabular}{|c|c|c|c|}
\hline Parameter & $\begin{array}{c}\text { Upper } \\
\text { East }\end{array}$ & $\begin{array}{l}\text { Upper } \\
\text { West }\end{array}$ & Northern \\
\hline $\begin{array}{l}\text { Total number of } \\
\text { birds } \\
\text { Number died } \\
\text { Number survived } \\
\text { Percentage } \\
\text { survived } \\
\text { Percentage } \\
\text { mortality (\%) }\end{array}$ & $\begin{array}{c}86 \\
1 \\
85 \\
98.8 \\
1.2\end{array}$ & $\begin{array}{c}79 \\
- \\
79 \\
100 \\
-\end{array}$ & $\begin{array}{c}78 \\
2 \\
76 \\
97.4 \\
2.2\end{array}$ \\
\hline
\end{tabular}

Mortality among birds from the three regions was generally low, resulting in high survival rates among the birds. This reveals that guinea fowls are actually resistant to diseases. Almost all the deaths recorded were as a result of pecking. The low mortality is also an indication that management was effective.

\section{CONCLUSIONS:}

It was observed from the study that birds from Upper West Region consumed less feed but produced more eggs, efficient in feed conversion, high body weight gain despite their small size as compared to their counterparts from Upper East Region and Northern Regions. The outstanding high performance of the birds from Upper West Region could emanate partly from their genotypes. However, birds from Northern Region recorded high fertility and did fairly well in the egg production, body weight and daily weight gain. Birds from Upper East Region performed comparatively lower despite their general large body size. The study revealed that birds from Upper East Region will be good for meat production, those from Upper West suitable for egg production and birds from Northern Region can be used for both meat and egg production. Therefore with proper and intensive selection alongside good feeding and management, the local scavenging guinea fowl in terms of meat and egg production can be improved. 


\section{RECOMMENDATIONS}

- Based on this study, birds from the Upper West Region are recommended for egg production, Upper East Region birds for meat and Northern Region birds for both meat and egg production.

- Further studies should be conducted into the reproductive parameters such as the egg fertility and mating ratio of the bird.

- Sponsorship should be maintained to continue the Guinea Fowl Project in the University.

\section{REFERENCES}

Adjetey, N. A. A. (2006). A Comparative Growth Performance of Growing Indigenous Guinea Fowls from Upper East, Upper West and Northern Regions of Ghana. A dissertation Submitted to the Animal Science Department, Faculty of Agriculture, University for Development Studies for the Award of B. Sc. Degree in Agricultural Technology. Pp:1-20.

Anamoh, B. (1975). The Effect of the Mating Ratio of Guinea Fowl, Male to Female Ratios on Percentage Fertility and Hatchability of Guinea Fowl Eggs. B Sc. Dissertation Submitted to the Department of Animal Science, Faculty of Agriculture, University of Ghana, Legon. Pp: 30-37.

Biswas, E. R. J. (1999). Guinea Fowl Management and Welfare of Farm Animals. University Federation for Animal Welfare Farm Handbooks, $4^{\text {th }}$ Edition, Holstein and Co. Ltd, Amersham, Bucks, U. K. Pp:273-277.
Daghir, N. J. (1995). Poultry Production in Hot Climates. Pp: 72-99.

Kekeocha, C. C. (1984). Livestock Production and Health in Ghana. Pp: 17-133.

Koney, E. M. B. (1992). Poultry Health and Production in Ghana. Pp: $19-20$

Koney, E. M. B. (1993). Poultry Health and production in Ghana. East Legon Veterinary Center. Pp: $101-106$.

Machedeyi, F. C. Sibanda, S. Kusina, J. and Makuza, S. (2004). The Village Chicken Production System in Rushinga District of Zimbabwe. Livestock Research for Rural Development: 16(6).

Manganga, S. L. S. and Haule, K. S. (1994). Domestication of Guinea Fowl. A case Study of Morogoro Municipal, Tanzania. Wildlife and Nature Conservation in Africa 14: 14-28.

Maphosa, T. Kusina, J. F. Sibanda, N. J. Makuza, S. M. and Sibanda, S. (2002). Village Chicken Production in Small Farming Areas in Zimbabwe. Poster Presentation. Poster (J-17), Copenhagen, Denmark.

Oluyemi, J. A. and Roberts, F. A. (1979). Poultry Production in Warm Wet Climates. Macmillan Publishers Ltd. London. Pp 101-120.

Savanna Agricultural Research Institute (SARI) (2004). Meteorological Department, Nyankpala, Tamale, Ghana.

Smith, A. J. (1990). The Tropical Agriculturalist. Centre for Vet. Medicine, University of Edinburgh. Pp: 20-67.

Teye, G. A. and Gyawu, P. (2002). A Guide to Guinea Fowl Production in Ghana. Pp: II-14. 